\title{
Effect of curcumin on the viability of SKOV3 cells and its probable mechanism of action
}

\author{
Wang Dan ${ }^{1}$, Xu Cheng ${ }^{2}$, Zhang Fei-Fei ${ }^{1}$, Zeng Bao-Jin ${ }^{1 *}$ \\ ${ }^{1}$ Obstetrics and Gynecology Department, Taizhou Hospital of Zhejiang Province affiliated to Wenzhou Medical University, \\ Taizhou, ${ }^{2}$ Pathology Department, Enze Hospital, Taizhou Enze Medical Center (Group). Taizhou, China \\ *For correspondence: Email: zengbaojin@aliyun.com
}

Sent for review: 25 September 2021

Revised accepted: 22 March 2021

\begin{abstract}
Purpose: To study the influence of curcumin on the survival of SKOV3 cells and the potential molecular mechanism of action.

Methods: SKOV3 cell proliferation was measured using MTT assay. Gene expression levels were assayed using QRT-PCR assay, while protein expression was determined with western blotting.

Results: Cell viability was reduced by curcumin at doses of 20, 40 and $80 \mu M(p<0.05)$ in a dosebased fashion. Protein expression levels of Bax, caspase-3 and caspase- 9 were upregulated by curcumin, while $\mathrm{Bcl}-2$ protein level was downregulated $(p<0.05)$.

Conclusion: These results demonstrate that curcumin inhibits cell proliferation by promoting the protein expressions of pro-apoptotic genes (Bax, caspase-3 and caspase-9) while suppressing Bcl-2 protein level. Therefore, curcumin might be a novel alternative therapy for ovarian cancer.
\end{abstract}

Keywords: Curcumin, SKOV3, Apoptosis, Ovarian cancer

\begin{abstract}
This is an Open Access article that uses a fund-ing model which does not charge readers or their institutions for access and distributed under the terms of the Creative Commons Attribution License (http://creativecommons.org/licenses/by/4.0) and the Budapest Open Access Initiative (http://www.budapestopenaccessinitiative.org/read), which permit unrestricted use, distribution, and reproduction in any medium, provided the original work is properly credited.

Tropical Journal of Pharmaceutical Research is indexed by Science Citation Index (SciSearch), Scopus, International Pharmaceutical Abstract, Chemical Abstracts, Embase, Index Copernicus, EBSCO, African Index Medicus, JournalSeek, Journal Citation Reports/Science Edition, Directory of Open Access Journals (DOAJ), African Journal Online, Bioline International, Open-J-Gate and Pharmacy Abstracts
\end{abstract}

\section{INTRODUCTION}

Cancer of the ovaries (CO) ranks among the major causes of cancer-related mortality in women globally $[1,2]$. It is associated with very poor treatment outcomes, with a low 5-year survival [3]. Most CO cases are aggressive, highly metastatic and chromosomally instable $[4,5]$. The insidious nature of $\mathrm{CO}$ and inadequate screening strategies invariably result in delayed diagnosis in patients. The treatment option for CO involves chemotherapy, but it is associated with undesirable adverse effects such alopecia, tiredness, blood loss and deleterious changes in bone marrow, all of which are depressing to the patient [6].

Mixtures of synthetic drugs and herbal extracts have been effectively used for treatment of cancers [7,9]. Apart from producing good therapeutic effects, herbal products have very low toxicity and minimal adverse effects, relative to orthodox anticancer drugs. Thus, herbal products may serve as effective and alternative remedies to conventional drugs used in cancer therapy.

Curcumin, a polyphenolic compound isolated from turmeric, possesses antioxidant and anti- 
inflammatory properties. Studies have demonstrated that curcumin exerts anticarcinogenic potential through induction of apoptotic changes and suppression of angiogenesis [10]. Moreover, evidence for in vivo anti-cancer effects of curcumin have been reported in several investigations which showed its anti-lymphoma properties [11,12]. However, not much is known about the effect of curcumin on DLBCL. This study was aimed at investigating the influence of curcumin on the proliferative potential of SKOV3 cell lines, and the molecular mechanism of action.

\section{EXPERIMENTAL}

\section{Chemicals}

Curcumin, MTT and N-acetylcysteine (NAC) were products of Sigma. All other reagents and media were of the highest grade.

\section{Anti-tumor assays}

The SKOV3 cell lines were cultured in MEM spiked with $5 \% \mathrm{FBS}$ at $37{ }^{\circ} \mathrm{C}$ in a $5 \% \mathrm{CO}_{2}$ incubator. The viability of SKOV3 cancer cells was measured using MTT method. The cells were seeded in 96-well plates at a density of $3 \times$ $10^{3}$ cells/well for each cancer cell line. Curcumin was solubilized DMSO to levels of 20,40 and 80 $\mu \mathrm{M}$ in each well. A well without curcumin served ss control. After incubating the cells for $4 \mathrm{~h}, 20$ $\mu \mathrm{L}$ of DMSO was added to every well, and incubation was continued for three days, prior to addition of MTT (20 $\mu \mathrm{L} /$ well $)$ and further incubation for $5 \mathrm{~h}$. Thereafter, the medium was replaced with DMSO to solubilize the resultant formazan crystals, and the absorbance of each well was read at $550 \mathrm{~nm}$ in a microplate reader. From the absorbance values, the ED50 was calculated with reference to cells unexposed to curcumin.

\section{Western blotting assay}

Harvested SKOV3 cells were subjected to lysis in RIPA buffer spiked with protease and phosphatase blockers. The protein level in the lysate was measured with bicinchoninic acid method. The proteins were subjected to SDS-
PAGE and transferred to polyvinylidene difluoride membranes which were incubated with non-fat milk solution ( $5 \%$ ) to block non-specific binding of the blot. Then, the membranes were incubated for $12 \mathrm{~h}$ at $4^{\circ} \mathrm{C}$ with appropriate $1^{\circ}$ antibodies, followed by incubation with HRP-conjugated $2^{\circ}$ antibody at laboratory temperature for $60 \mathrm{~min}$. The protein bands were subjected to ECL.

\section{qRT-PCR}

TRIzol reagent was applied for extraction of total RNA from the cells. The RNA $(1.0 \mu)$ was reverse-transcribed to cDNA. Then, qRT-PCR was carried out in Bio-Rad iCycler iQ5 instrument (Bio-Rad Lab. Inc.). The qRT-PCR reaction mixture comprised $12.5 \mu \mathrm{L}$ Maxima SYBR Green qPCRMaster mix, sense and anti-sense primers $\left(0.3 \mu \mathrm{L}\right.$ each), $5.9 \mu \mathrm{L} \mathrm{H}_{2} \mathrm{O}$ free from nuclease, and $6 \mu \mathrm{L}$ cDNA template. Cycling conditions were: initial denaturation at $95^{\circ} \mathrm{C}$ for $10 \mathrm{~min}, 45$ cycles at $95^{\circ} \mathrm{C}$ for $15 \mathrm{sec}, 60^{\circ} \mathrm{C}$ annealing for $20 \mathrm{sec}$, extension at $72^{\circ} \mathrm{C}$ for $30 \mathrm{sec}$, in a total of 61 cycles. $\beta$-Actin was used as internal control. The relative gene expressions were calculated from a standard calibration curve. The primer sequences used are presented on Table 1.

\section{Statistics}

Data are presented as mean \pm standard deviation. Analysis of variance and Tukey test were used for comparing means amongst the groups. All data analyses were done with GraphPad Prism 5.0 software. Values of $p<0.05$ were assumed as indicative of statistical significance.

\section{RESULTS}

\section{Effect of curcumin on viability of SKOV3 cells}

To illustrate the effect of curcumin on the viability of SKOV3 cells, the potency of curcumin-treated SKOV3 cells was measured with MTT method. At doses below $20 \mu \mathrm{M}$, curcumin had no effect of cell viability. However, dose-based suppression of cell viability occurred at curcumin doses $>20$ $\mu \mathrm{M}$ (Figure 1).

Table 1: Primers used

\begin{tabular}{lll}
\hline Gene & Sense & Anti-sense \\
\hline Bax & 5'-TGCTTCAGGGTTTCATCCAGG-3' & 5'-TGGCAAAGTAGAAAAGGGCGA-3' \\
Bcl-2 & 5'-GGATTGTGGCCTTCTTTGAG-3' & 5'-CCAAACTGAGCAGAGTCTTC-3' \\
Caspase 3 & 5'-AACTGGACTGTGGCATTGAG-3' & 5'-ACAAAGCGACTGGATGAACC-3' \\
Caspase 9 & 5'-GGAAGAGGGACAGATGAATG-' & 5'-TTGTTTGGCACCACTCAG-3' \\
ß-actin & 5'-GTGGGGCGCCCCAGGCACCA-3' & 5'-CTCCTTAATGTCACGCACGATTTC-3' $^{2}$ \\
\hline
\end{tabular}




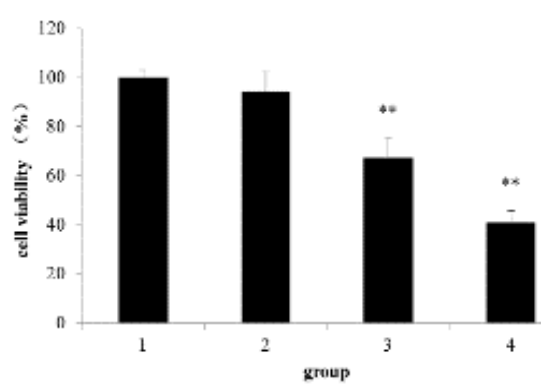

Figure 1: Curcumin affected SKOV3 cell growth. Group 1 = untreated cells; groups 2, 3 and 4 are 20, 40 and $80 \mu \mathrm{M}$ curcumin, respectively; ${ }^{* *} p<0.01$, vs group 1

Influence of curcumin on apoptotic protein levels in SKOV3 cells

To determine the influence of curcumin on the apoptosis proteins of SKOV3 cells, the apoptosis protein expression levels in cells exposed to curcumin at doses of 20,40 , and $80 \mu \mathrm{M}$ were assayed using Western blotting. At doses $>20$ $\mu \mathrm{M}$, curcumin produced dose-dependent downregulation of $\mathrm{Bcl}-2$ and upregulation of caspase-3, Bax and caspase-9 (Figure 2).

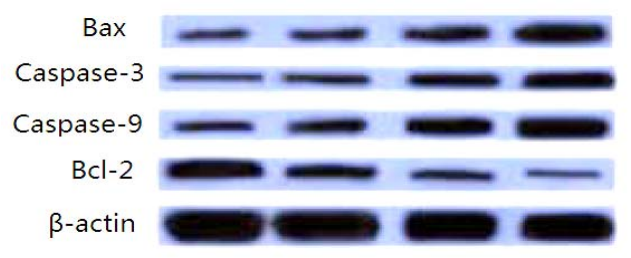

Figure 2: Curcumin affects apoptotic protein levels in SKOV3 cells. Group 1 = untreated; groups 2, 3 and 4 are 20,40 and $80 \mu \mathrm{M}$ curcumin, respectively

\section{Effect of curcumin on apoptosis gene expression levels in SKOV3 cells}

Curcumin, at levels $>20 \mu \mathrm{M}$, downregulated the mRNA expressions of the anti-apoptotic gene Bcl-2 and enhanced mRNAs of Bax, caspase-3 and caspase-9 in SKOV3 cells in a dose-based manner (Figure 3).

\section{DISCUSSION}

The anticancer effect of curcumin has been demonstrated in several types of cancers $[13,14]$. Studies have shown that curcumin affects several metabolic processes through many molecular targets [15]. It has also been reported that curcumin does not exert toxic effects in humans even if administered at a dose as high as $10 \mathrm{~g}$ daily [16]. The present study has shown that curcumin suppressed the growth of SKOV3 cancer cells.

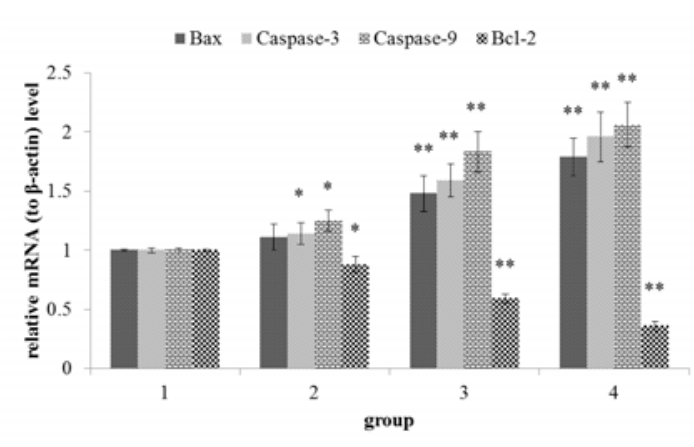

Figure 3: Effect of curcumin on expression levels of apoptotic genes in SKOV3 cells. Group 1 = untreated; groups 2,3 and 4 are 20,40 and $80 \mu \mathrm{M}$ curcumin, respectively. ${ }^{*} P<0.05 ;{ }^{* *} p<0.01$, vs group 1

It belongs to the Bcl-2 family_of proteins that regulate cell death (apoptosis) [17]. The ratio of $\mathrm{Bax}$ to $\mathrm{Bcl}-2$ is a standard indicator of apoptosis [18] and pro-apoptotic potential [19]. Caspase levels (caspases-3, 8 and 9) are associated with apoptotic potential $[20,21]$. In this study, curcumin exposure induced changes in concentrations of $\mathrm{Bax}$ and $\mathrm{Bcl}-2$. Of particular relevance is the curcumin-induced decrease in Bax level, which point to cell death via the intrinsic route.

\section{CONCLUSION}

The findings of this study show that curcumin lowers SKOV3 cell viability, increases proapoptotic proteins, and decreases Bcl-2 level, thereby inhibiting SKOV3 tumor growth. These findings may be helpful in the development of a new therapeutic strategy for cancer management.

\section{DECLARATIONS}

\section{Conflict of interest}

No conflict of interest is associated with this work.

\section{Contribution of authors}

We declare that this work was done by the authors named in this article and all liabilities pertaining to claims relating to the content of this article will be borne by the authors.

\section{Open Access}

This is an Open Access article that uses a funding model which does not charge readers or their institutions for access and distributed under the terms of the Creative Commons Attribution 
License (http://creativecommons.org/licenses/by/ 4.0) and the Budapest Open Access Initiative (http://www.budapestopenaccessinitiative.org/rea d), which permit unrestricted use, distribution, and reproduction in any medium, provided the original work is properly credited.

\section{REFERENCES}

1. Waldmann A, Eisemann N, Katalinic A. Epidemiology of Malignant Cervical, Corpus Uteri and Ovarian Tumours Current Data and Epidemiological Trends. Geburtshilfe Frauenheilkd. Thieme Medical Publishers; 2013; 73: 123-129.

2. Siegel RL, Miller KD, Jemal A. Cancer statistics, 2017. CA Cancer J Clin. 2017; 67:7-30.

3. Jelovac $D$, Armstrong $D K$. Recent progress in the diagnosis and treatment of ovarian cancer. CA Cancer $J$ Clin 2011; 61: 183-203.

4. Vang R, Shih I-M, Kurman RJ. Ovarian low-grade and high-grade serous carcinoma: pathogenesis, clinicopathologic and molecular biologic features, and diagnostic problems. Adv Anat Pathol. 2009; 16: 267282.

5. Kurman RJ. Origin and molecular pathogenesis of ovarian high-grade serous carcinoma. Ann Oncol. 2013; 24: $x 16-x 21$.

6. Mukhtar E, Adhami VM, Mukhtar H. Targeting microtubules by natural agents for cancer therapy. Mol Cancer Ther. 2014; 13:275-284.

7. Aljuffali IA, Fang CL, Chen CH, Fang JY. Nanomedicine as a strategy for natural compound delivery to prevent and treat cancers. Curr. Pharm. Des. 2016; 22:42194231.

8. Davatgaran-Taghipour Y, Masoomzadeh S, Farzaei MH, Bahramsoltani R, Karimi-Soureh Z, Rahimi R, Abdollahi M. Polyphenol nanoformulations for cancer therapy: Experimental evidence and clinical perspective. Int. J. Nanomed. 2017; 12:2689-2702.

9. Mbaveng AT, Kuete V, Efferth T. Potential of central, eastern and western Africa medicinal plants for cancer therapy: Spotlight on resistant cells and molecular targets. Front. Pharmacol. 2017; 8:343.

10. $A B$ Kunnumakkara, $P$ Anand, $B B$ Aggarwal. Curcumin inhibits proliferation, invasion, angiogenesis and metastasis of different cancers through interaction with multiple cell signaling proteins. Cancer Lett., 269 (2008), pp. 199-225.

11. J Guorgui, R Wang, G Mattheolabakis, GG Mackenzie. Curcumin formulated in solid lipid nanoparticles has enhanced efficacy in Hodgkins lymphoma in mice. Arch. Biochem. Biophys 2018; 648: 12-19.

12. L Das, M Vinayak. Long-term effect of curcumin downregulates expression of tumor necrosis factor-alpha and interleukin-6 via modulation of E26 transformationspecific protein and nuclear factor-kappaB transcription factors in livers of lymphoma bearing mice. Leuk. Lymphoma 2014; 55: 2627-2636.

13. Kunnumakkara AB, Anand P, Aggarwal BB. Curcumin inhibits proliferation, invasion, angiogenesis and metastasis of different cancers through interaction with multiple cell signaling proteins. Cancer Lett 2008; 269; 199-225

14. SH Wu, LW Hang, JS Yang, HY Chen, HY Lin, JH Chiang, CC Lu, JL Yang, TY Lai, YC Ko, JG Chung. Curcumin induces apoptosis in human non-small cell lung cancer NCl-H460 cells through ER stress and caspase cascade- and mitochondria-dependent pathways. Anticancer Res 2010; 30: 2125-2133

15. Goel A, Kunnumakkara AB, Aggarwal BB. Curcumin as "Curecumin": from kitchen to clinic Biochem Pharmacol 2008; 75: 787-809

16. Cheng AL, CH Hsu, JK Lin, MM Hsu, YF Ho, TS Shen, JY Ko, JT Lin, BR Lin, W Ming-Shiang, et al. Phase I clinical trial of curcumin, a chemopreventive agent, in patients with high-risk or pre-malignant lesions. Anticancer Res 2001; 21: 2895-2900

17. Chen C, Liu TS, Zhao SC, Yang WZ, Chen ZP, Yan Y. XIAP impairs mitochondrial function during apoptosis by regulating the Bcl-2 family in renal cell carcinoma. Exp Ther Med. 2018; 15(5): 4587-4593.

18. Glory A, Bettaieb A, Averill-Bates DA. Mild thermotolerance induced at $40^{\circ} \mathrm{C}$ protects cells against hyperthermia-induced pro-apoptotic changes in Bcl-2 family proteins. Int J Hyperthermia. 2014; 30(7): 502512.

19. Liu Y, Zuo H, Wang Y, Tian L, Xu X, Xiong J, Pei X. Ethanol promotes apoptosis in rat ovarian granulosa cells via the Bcl-2 family dependent intrinsic apoptotic pathway. Cell Mol Biol (Noisy-le-grand). 2018 Jan 31;64(1):118-125.

20. Anderson SL, Townsend HGG, Singh B. Role of toll-like receptor 4 and caspase-3, -8 , and -9 in lipopolysaccharide-induced delay of apoptosis in equine neutrophils. Am J Vet Res. 2018 Apr;79(4):424-432.

21. Zhao W, Tang L, Gao S, Xin L, Zhang H, Li Y. Junduqing extractive promotes the apoptosis of nasopharyngeal carcinoma cells through down-regulating $\mathrm{Mcl}-1$ and $\mathrm{BCl}-$ $x L$ and up-regulating Caspase-3, Caspase-8 and Caspase-9. Artif Cells Nanomed Biotechnol. 2019 Dec;47(1):3904-3912. 